\title{
Carcass and non-carcass components of feedlot ewes subjected to increasing levels of concentrate in the diet
}

\author{
Componentes carcaça e não-carcaça de borregas confinadas submetidas a níveis \\ crescentes de concentrado na dieta
}

\author{
MORAIS, Maria da Graça ${ }^{1}$; SILVA, Rafaele Alcântara da ${ }^{1}$; COMPARIN, Marco \\ Aurélio Scarton ${ }^{1 *}$; FEIJÓ, Gelson Luís Dias ${ }^{2}$; RIBEIRO, Caroline Bertholini ${ }^{1}$; \\ WALKER, Catherine Cecilia ${ }^{1}$; BENTO, Anderson Luiz de Lucca ${ }^{1}$; ÍTAVO, Camila \\ Celeste Brandão Ferreira ${ }^{1}$
}

\footnotetext{
${ }^{1}$ Universidade Federal de Mato Grosso do Sul, Faculdade de Medicina Veterinária e Zootecnia, Programa de Pós-Graduação em Ciência Animal, Campo Grande, Mato Grosso do Sul, Brasil.

${ }^{2}$ Empresa Brasileira de Pesquisa Agropecuária, Centro Nacional de Pesquisa de Gado de Corte, Campo Grande, Mato Grosso do Sul, Brasil.

*Endereço para correspondência: mascvet@yahoo.com.br
}

\section{SUMMARY}

The objective of this study was to evaluate the effect of increasing levels of concentrate on the production of carcass and non-carcass components of feedlot ewes. Twenty-four crossbred ewes were randomly distributed in four treatments: diet with $20 \% ; 40 \%$; $60 \%$; and $80 \%$ concentrate. Animals were slaughtered when those receiving the diet with $80 \%$ concentrate reached adult live weight $(50 \mathrm{~kg}$ LW). The data were analyzed by variance and regression analyses. The weights of the shoulder and leg rise linearly with the increase in the levels of concentrate, but shoulder yield was not affected, with an average of $16 \%$, and the leg yield reduced linearly (28 $\mathrm{g}$ for each $1 \%$ concentrate added). The percentage value of the viscera reduced linearly, as well as those of head and paws. The non-carcass components represented values of $34.64 ; 38.60 ; 38.55$; and $39.88 \%$ of the LW for the levels of 20, 40, 60 and $80 \%$ of concentrate, respectively. The weight of the cuts is affected positively by the increase in the levels of concentrate. The increase in the levels of concentrate promotes lower percentage of viscera and increase in the deposition of back fat of the commercial meat cuts.

Keywords: byproducts, fat, leg, organ, shoulder, viscera

\section{RESUMO}

Objetivou-se avaliar o efeito de níveis crescentes de concentrado sobre a produção dos componentes carcaça e não-carcaça de borregas confinadas. Vinte e quatro borregas mestiças foram aleatoriamente distribuídas em quatro tratamentos: dieta com 20\%; 40\%; 60\%; $80 \%$ de concentrado. Os animais foram abatidos quando aqueles que recebiam a dieta $80 \%$ de concentrado atingiram o peso adulto $(50 \mathrm{~kg}$ PV). Os dados foram analisados por meio de análise de variância e regressão. Os pesos da paleta e da perna cresceram linearmente com o aumento dos níveis de concentrado, porém, o rendimento da paleta não foi influenciado com média de $16 \%$, e o rendimento da perna reduziu linearmente ( $28 \mathrm{~g}$ para cada $1 \%$ de concentrado adicionado). $\mathrm{O}$ valor percentual das vísceras reduziu linearmente, assim como da cabeça e patas. Os componentes não-carcaça representaram valores de 34,64; 38,60; 38,55 e $39,88 \%$ do PV para os níveis de 20, 40, 60 e $80 \%$ de concentrado, respectivamente. Concluise que os pesos dos cortes são influenciados positivamente pelo aumento dos níveis de concentrado. O aumento dos níveis de concentrado proporciona menor percentual de vísceras e aumento na deposição de gordura subcutânea dos cortes cárneos comerciais.

Palavras-chave: gordura, paleta, perna, órgãos, subprodutos, vísceras 


\section{INTRODUCTION}

Improved measures in the production of lambs can be achieved (PINHEIRO et al., 2009), since feeding strategies can combine feed efficiency with the final product quality. However, studies involving - that measures in sheep are almost inexistent in the scientific literature, especially on females (PINHEIRO et al., 2009).

In animals raised for meat production, the carcass is the main commercialized product, besides the cuts. Meat cuts in individualized pieces associated with how to sell the product are important factors in the commercialization. The type of cut varies according to the different geographic regions, especially among countries (ALVES et al., 2003).

The composition of the regions of the body, coupled with those of tissues, are variables utilized for the determination of the classification of a carcass (FRESCURA et al., 2005).

However, from the technical point of view, the concept of the commercialization of the animal as a whole must take into account not only the carcass components (cuts), but also the non-carcass components, also called "quinto quarto". The latter are composed of the digestive tract and its content, skin, head, paws, tail, lungs, trachea, liver, heat, kidneys, omental, mesenteric, renal and pelvic fats, spleen and reproductive and urinary systems (YAMAMOTO et al., 2004).

According to Galvani et al. (2008), the non-carcass components can represent up to $40 \%$ of the live weight of sheep, and they are influenced by genetic potential, age, live weight, sex, and most of all, feeding. However, the influence of the diet composition on the production of visceral organs is still not very clear.
For Carvalho et al. (2007), the economic valuation of these components comprise from the feeding (as in the case of heart, liver and kidneys) to the clothing industry (in the case of hides), going through other purposes (medical, pharmaceutical, etc.) In fact, although discarded in most of the situations, some organs and viscera could be utilized in exotic or typical foods, aggregating value to the product as a whole (SILVA SOBRINHO et al., 2002).

Therefore, the objective of this study was to evaluate the increasing levels of concentrate on the production of carcass (weight, yield and tissue composition of the commercial cuts) and non-carcass components (organs, viscera and byproducts) of feedlot ewes.

\section{MATERIAL AND METHODS}

The experiment was conducted in the Faculty of Veterinary Medicine and Animal Science of Universidade Federal de Mato Grosso do Sul, in Campo Grande, MS, Brazil, from July to December 2009. Twenty-four newly weaned crossbred ewes were used. Animals were of approximately 2 months of age, originated from the crossing with wool animals (crossings of Texel, Ile de France and animals of undefined breed with initial average live weight of $18 \mathrm{~kg}$, and treated against endoparasites.

The experimental design used was completely randomized, with six ewes per treatment. The animals were placed in individual stalls provided with trough for roughage and concentrate, drinker, and trough for mineral supplement. Ewes were subjected to four diets containing increasing levels of concentrate: (1) diet with 20\%; (2) diet 
with 40\%; (3) diet with 60\%; and (4) diet with $80 \%$ concentrate. All the animals received feed ad libitum, supplied twice daily, adjusted according to the individual live weight. The control of intake was performed daily.

The diets were formulated according to the NRC (2007) so that the daily weight gains would vary from 100 to $250 \mathrm{~g} /$ day, according to the increasing levels of concentrate. In all the treatments, a single concentrate was added, containing $21.46 \% \mathrm{CP}$ and $78.19 \%$ TDN, based on corn and soybean meal, shredded Tifton 85 (Cynodon spp.) hay containing $9.81 \%$ crude protein (CP) and $54.58 \%$ total digestible nutrients (TDN), as roughage. Variable amounts of urea were added to the diets of 20 to $60 \%$ of concentrate, so as to have increasing protein and energy values. Diets presented 13.34; 16.32; 19.33; and 22.37\% CP and 60.10; 68.91; 74.40 ; and $76.73 \%$ TDN for the levels of $20,40,60$ and $80 \%$ concentrate, respectively. Water and mineral supplement were permanently available.

All animals were slaughtered at the time when those, which received the diet with greatest percentage of concentrate $(80 \%)$ reached adult weight, at around $50 \mathrm{~kg}$ live weight (LW). The feedlot period was of approximately 120 days.

The slaughter of animals took place in the Laboratory of Carcasses of Embrapa Gado de Corte, in Campo Grande, MS, Brazil. Animals were fasted of solids for 18 hours prior to slaughter, followed by weighing for obtainment of the live weight at slaughter (LWS).

The slaughter was conducted with the stunning of animals by brain concussion (with captive bolt pistol), followed by sectioning of the carotid artery and jugular vein. All the blood was collected and weighed with a bucket. Head, paws and genitals were skinned, eviscerated and removed for determination of warm carcass weight (WCW).

Carcasses were taken to cold chamber at a temperature of $\pm 4^{\circ} \mathrm{C}$ for a period of 24 hours, and subsequently weighed for the obtainment of cold carcass weight (CCW) and split in half, and halfcarcasses were weighed. The right halfcarcass was subdivided in six commercial cuts (neck, shoulder, rack (or rib), Frenched rack (or commonly carré), loin and leg), according to the methodology suggested by Santos et al. (2001).

The cuts were weighed individually and their respective yields were calculated by the ratio between the weight of the cut and the weight of the right halfcarcass, expressed in percentage.

For the determination of the tissue composition of the cuts, the muscle was separated into muscle + intermuscular fat + intramuscular fat, backfat (BF) and bones for shoulder, leg and loin, whereas for neck, rack and carré, there was only separation of BF. Each tissue component was expressed in percentage (ratio between the tissue component with the weight of its respective cut). Besides, the weight of the backfat of all cuts was summed for the obtainment of the total backfat weight (TBF) of the carcass.

The non-carcass components were weighed individually, subdivided in organs (tongue, lung + trachea + esophagus, heart, liver + empty gallbladder, kidneys, spleen, reproductive system, udder), viscera (rumen, reticulum, omasum, abomasum, small and large intestines) and byproducts (blood, skin + wool, head, paws and adipose deposits of omental + mesenteric, kidney + pelvic and subcutaneous fat)

The components of the gastrointestinal tract (GIT) were weighed full and empty for the determination of the content of the GIT (CGIT). In addition, 
the bladder and gallbladder were also weighed full and subsequently empty, for determination of the empty body weight (EBW), calculated from the difference between LWS and CGIT, bladder and gallbladder empty.

From the determination of EBW, the non-carcass components were expressed in percentage (the ratio between the weight of each non-carcass components in relation to the EBW of each animal). The data were analyzed by ANOVA and regression analysis. The models were chosen based on the significance of the regression coefficients, utilizing the $\mathrm{F}$ test, adopting $5 \%$ of probability, in the determination coefficient and in the variable studied utilizing software Sistema de Análises Estatísticas e Genéticas (UFV, 1997), according to the following model: $Y_{i j}=\boldsymbol{\mu}+\mathbf{C}_{\mathbf{i}}+\mathbf{e}_{\mathrm{ij}}$, in which $\mathbf{C}$ : level of concentrate (20; $40 ; 60$ and $80 \%$ ) and e: random error associated with the observation.

\section{RESULTS AND DISCUSSION}

The increasing inclusion of concentrate in the diet of ewes increased the weights of shoulder, leg, rack, neck and carré linearly (Table 1), and only loin presented quadratic effect, with the highest weight obtained with the use of $68.54 \%$ of concentrate in the diet. It is important to say that the treatments used interfere directly over weight at slaughter of animals, and this reflects on the other parameters.

Table 1. Means, coefficients of variation (CV), regression equations and determination coefficients $\left(\mathrm{R}^{2}\right)$ for live weight at slaughter (LWS), cold carcass weight $(\mathrm{CCW})$, half-carcass components weight $(\mathrm{HCW})$ and cut yields in the right half-carcass according to the levels of concentrate in the diet

\begin{tabular}{|c|c|c|c|c|c|c|c|}
\hline \multirow{2}{*}{ Variables $^{1}$} & \multicolumn{4}{|c|}{ Level of concentrate $^{2}$} & \multirow{2}{*}{$\mathrm{CV}$} & \multirow{2}{*}{ Regression } & \multirow{2}{*}{$2^{2}$} \\
\hline & 20 & 40 & 60 & 80 & & & \\
\hline LWS (kg) & 36.23 & 39.77 & 43.61 & 47.86 & 9.23 & $\mathrm{Y}=32.1518+0.197970 \mathrm{C}^{*}$ & 0.99 \\
\hline $\mathrm{CCW}(\mathrm{kg})$ & 15.67 & 18.78 & 21.72 & 24.63 & 9.17 & $\mathrm{Y}=12.7417+0.149167 \mathrm{C}^{*}$ & 0.99 \\
\hline $\mathrm{HCW}(\mathrm{kg})$ & 7.87 & 9.43 & 10.72 & 12.25 & 8.83 & $Y=6.45975+0.0721458 C^{*}$ & 0.99 \\
\hline Shoulder (kg) & 1.31 & 1.49 & 1.68 & 1.93 & 9.50 & $\mathrm{Y}=1.09283+0.0102700 \mathrm{C}^{*}$ & 0.99 \\
\hline Loin $(\mathrm{kg})$ & 0.63 & 0.84 & 0.99 & 0.95 & 12.24 & $\begin{array}{c}\mathrm{Y}=0.253417+0.0213342 \mathrm{C}- \\
0.000155625 \mathrm{C}^{2} *\end{array}$ & 0.99 \\
\hline $\operatorname{Leg}(\mathrm{kg})$ & 2.52 & 2.96 & 3.36 & 3.67 & 8. & $\mathrm{Y}=2.16100+0.0193917 \mathrm{C}^{*}$ & 0.99 \\
\hline $\mathrm{R}$ & 1.53 & 1.84 & 2.09 & 2.54 & 12.57 & $Y=1.17817+0.0$ & 0.99 \\
\hline & 0.80 & 1.00 & 1.16 & 1.29 & 15.12 & $656333+0.0$ & 0.99 \\
\hline & 1.01 & 1.27 & 1.32 & 1.74 & 10.02 & $Y=0.769500+0.0113450 C^{*}$ & 0.92 \\
\hline \multicolumn{8}{|c|}{ Cut yield (\%) } \\
\hline Shoulder (\%) & 16.68 & 15.76 & 15.79 & 15.77 & 6.17 & - & - \\
\hline Loin $(\%)$ & 7.96 & 8.81 & 9.26 & 7.83 & 9.27 & $\begin{array}{c}\mathrm{Y}=5.59498+0.142979 \mathrm{C}- \\
0.00142578 \mathrm{C}^{2 *}\end{array}$ & 0.92 \\
\hline $\mathrm{L}$ & 32.05 & 31.21 & 31.41 & 30.08 & 3. & $\mathrm{Y}=32.6178-0.0286431 \mathrm{C}^{*}$ & 0.81 \\
\hline Rack (\%) & 19.48 & 19.48 & 19.49 & 20.75 & 6.82 & - & - \\
\hline Neck $(\%)$ & 10.14 & 10.57 & 10.87 & 10.55 & 9.89 & & 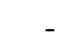 \\
\hline Carré (\%) & 12.81 & 13.35 & 12.39 & 14.27 & 6.25 & $\begin{array}{c}Y=6.41621+0.538525 C- \\
0.0127521 C^{2}+0.0000905889 C^{3}\end{array}$ & 0.82 \\
\hline
\end{tabular}

${ }^{1} \mathrm{C}=$ level of concentrate

${ }^{2}$ Averages followed by "*" are significant at a $5 \%$ probability; ns - not significant. 
According to Carvalho et al. (2007) the weight gain, carcass weight and cuts weights of lambs linearly decrease with increasing forage content and the reduction in the content of concentrate in the diet of feedlot lambs, confirming the influence of the weight gain on the income of cuts.

Similar data were obtained by Clementino et al. (2007), evaluating four levels of inclusion of concentrate $(30 ; 45 ; 60$ and $75 \%$ ) in diets for feedlot-finished uncastrated Dorper and Dorper x Santa Inês lambs, observed increasing linear effect of the weights of neck, shoulder, ribs, loin and leg. According to the authors, this increase in the weight of the cuts is probably due to the fact that the diets did not have the same amount of energy, thus favoring greater weights in animals that consumed a higher level of concentrate.

This explanation can also be used for the present study, since the diets also did not have the same amount of energy and protein, and the protein levels utilized were above the recommendations given by the NRC (2007) for the ewes utilized in this study, which impacts on the slaughter weight.

Concerning the yields of the cuts (Table 1), it can be observed that shoulder, rack and neck did not present effect in relation to the increase in the levels of concentrate, whose mean values were $16 \%, 19.8 \%$ and $10.5 \%$, respectively. However, loin yield presented quadratic effect, with the greatest yield achieved at the level of $50.14 \%$ of concentrate added to the diet. Leg yield, however, reduced linearly with increase of concentrate, with a reduction of 0.028 at every $1 \%$ of concentrate added to the diet. Carré yield presented cubic effect, whose maximum yield was obtained at the level of $32.08 \%$, and the lowest yield at $61.76 \%$ of concentrate included in the diet.
Shoulder and leg are the cuts of highest commercial value and represented about $48.73 ; 46.97 ; 47.20$ and $45.85 \%$ of the total yield of the cuts for the levels of 20 ; 40; 60 and $80 \%$ inclusion of concentrate, respectively, which demonstrates great participation in the total cuts, which was around 46-49\%.

Medeiros et al. (2009) affirmed that the lower yields of the prime cuts at the highest level of concentrate are a result from the process of early development of these parts, i.e., with increase in carcass weight, the proportion of the distal parts is reduced and the trunk region remains almost constant, since the growth is centripetal (Lawrence \& Fowler, 2002). This behavior was also observed in the present study, once shoulder yield was not influenced by the increasing levels of concentrate and leg yield reduced with inclusion of concentrate, which demonstrates early development of such cuts, due to the sustenance and aid in the locomotion of animals.

In an experiment with castrated crossbred Morada Nova lambs fed tifton hay and four levels of concentrate based on corn and soybean meal $(20 ; 40 ; 60$ and $80 \%$ ), slaughtered at $30 \mathrm{~kg} \mathrm{LW}$, Lawrence \& Fowler (2002) verified that neck yield grew linearly and shoulder and leg yields decreased with increase in concentrate, corroborating the result obtained for leg yield (Table 1).

As to the tissue components of the cuts (Table 2), it can observe that the weight of muscle, bones and subcutaneous fat of shoulder and leg presented positive linear effect according to the level of concentrate.

The percentage of shoulder muscle had a quadratic effect, and the inclusion level of $33.58 \%$ concentrate produced the maximum percentage deposition of muscle $(68.4 \%)$. 
Rev. Bras. Saúde Prod. Anim., Salvador, v.15, n.4, p.1038-1051 out./dez., 2014 http://www.rbspa.ufba.br ISSN 15199940

Table 2. Means, coefficients of variation $(\mathrm{CV})$, regression equations and determination coefficients $\left(\mathrm{R}^{2}\right)$ of the tissue components of the cuts according to the levels of concentrate in the diets

\begin{tabular}{|c|c|c|c|c|c|c|c|}
\hline \multirow{2}{*}{ Variables $^{1}$} & \multicolumn{4}{|c|}{ Level of concentrate ${ }^{2}$} & \multirow{2}{*}{$\mathrm{CV}$} & \multirow{2}{*}{ Regression } & \multirow{2}{*}{$\mathrm{R}^{2}$} \\
\hline & 20 & 40 & 60 & 80 & & & \\
\hline \multicolumn{8}{|c|}{ Shoulder } \\
\hline Muscle (g) & 892.23 & 1020.22 & 1126.38 & 1217.28 & 10.38 & $Y=793.700+5.40658 C^{*}$ & 0.99 \\
\hline Bone $(\mathrm{g})$ & 279.63 & 301.32 & 313.40 & 345.00 & 8.40 & $\mathrm{Y}=257.792+1.04092 \mathrm{C}^{*}$ & 0.97 \\
\hline $\mathrm{BF}(\mathrm{g})$ & 122.02 & 156.92 & 234.17 & 346.17 & 23.94 & $\mathrm{Y}=27.3917+3.74850 \mathrm{C}^{*}$ & 0.95 \\
\hline Muscle (\%) & 67.95 & 68.13 & 66.78 & 63.04 & 2.70 & $\begin{array}{c}\mathrm{Y}=65.5983+0.164241 \mathrm{C}- \\
0.00244562 \mathrm{C}^{2 *}\end{array}$ & 0.99 \\
\hline Bone $(\%)$ & 21.37 & 20.24 & 18.62 & 17.90 & 7.29 & $\mathrm{Y}=22.5402-0.0601597 \mathrm{C}^{*}$ & 0.98 \\
\hline $\mathrm{BF}(\%)$ & 9.34 & 10.52 & 13.66 & 17.90 & 19.23 & $Y=5.64876+0.144098 C^{*}$ & 0.95 \\
\hline $\mathrm{BF} / \mathrm{TBF}(\%)$ & 14.20 & 12.16 & 12.75 & 14.15 & 13.72 & - & - \\
\hline \multicolumn{8}{|c|}{ Leg } \\
\hline Muscle (g) & 1791.63 & 2077.77 & 2327.10 & 2504.12 & 9.10 & $\mathrm{Y}=1578.46+11.9339 \mathrm{C}^{*}$ & 0.99 \\
\hline Bone $(\mathrm{g})$ & 496.02 & 560.57 & 567.68 & 622.38 & 8.66 & $\mathrm{Y}=465.108+1.93108 \mathrm{C}^{*}$ & 0.93 \\
\hline $\mathrm{BF}(\mathrm{g})$ & 196.10 & 281.35 & 432.68 & 509.22 & 27.31 & $\mathrm{Y}=81.2950+5.47957 \mathrm{C}^{*}$ & 0.98 \\
\hline Muscle (\%) & 70.99 & 70.11 & 69.25 & 68.07 & 2.54 & $Y=72.0058-0.047987 C^{*}$ & 0.99 \\
\hline Bone $(\%)$ & 19.72 & 19.00 & 16.93 & 16.97 & 8.82 & $Y=20.7365-0.0515716 C^{*}$ & 0.88 \\
\hline $\mathrm{BF}(\%)$ & 7.81 & 9.46 & 12.77 & 13.86 & 22.91 & $Y=5.57721+0.108290 C^{*}$ & 0.96 \\
\hline $\mathrm{BF} / \mathrm{TBF}(\%)$ & 22.81 & 21.30 & 24.04 & 19.97 & 12.63 & - & - \\
\hline \multicolumn{8}{|c|}{ Loin } \\
\hline Muscle (g) & 357.80 & 462.92 & 537.47 & 509.23 & 13.51 & $\begin{array}{c}\mathrm{Y}=167.954+10.9786 \mathrm{C}- \\
0.0833437 \mathrm{C}^{2 *}\end{array}$ & 0.99 \\
\hline Bone $(\mathrm{g})$ & 164.65 & 222.13 & 206.20 & 181.42 & 18.36 & $\begin{array}{c}\mathrm{Y}=82.1750+5.31350 \mathrm{C}- \\
0.0514167 \mathrm{C}^{2 *}\end{array}$ & 0.89 \\
\hline $\mathrm{BF}(\mathrm{g})$ & 84.97 & 130.97 & 225.65 & 243.10 & 33.68 & $\mathrm{Y}=28.9000+2.84542 \mathrm{C}^{*}$ & 0.94 \\
\hline Muscle (\%) & 57.22 & 55.72 & 54.13 & 53.15 & 8.19 & - & - \\
\hline Bone $(\%)$ & 26.41 & 26.47 & 20.95 & 19.12 & 14.99 & $\mathrm{Y}=30.0921-0.137042 \mathrm{C}^{*}$ & 0.88 \\
\hline $\mathrm{BF}(\%)$ & 13.56 & 15.28 & 22.36 & 25.31 & 27.07 & $Y=8.54771+0.211602 C^{*}$ & 0.95 \\
\hline $\mathrm{BF} / \mathrm{TBF}(\%)$ & 9.88 & 9.68 & 12.45 & 9.87 & 23.96 & - & - \\
\hline \multicolumn{8}{|c|}{ Neck } \\
\hline $\mathrm{BF}(\mathrm{g})$ & 131.32 & 242.77 & 289.27 & 468.35 & 32.45 & $Y=18.5250+5.28800 C^{*}$ & 0.95 \\
\hline $\mathrm{BF}(\%)$ & 16.85 & 23.92 & 24.68 & 35.81 & 25.28 & $Y=10.9071+0.288189 C^{*}$ & 0.90 \\
\hline $\mathrm{BF} / \mathrm{TBF}(\%)$ & 15.27 & 18.15 & 15.49 & 19.05 & 21.26 & - & - \\
\hline \multicolumn{8}{|c|}{ Rack } \\
\hline $\mathrm{BF}(\mathrm{g})$ & 246.50 & 376.53 & 474.08 & 721.58 & 29.23 & $\mathrm{Y}=73.9750+7.61400 \mathrm{C}^{*}$ & 0.96 \\
\hline $\mathrm{BF}(\%)$ & 16.14 & 20.34 & 22.19 & 28.07 & 20.92 & $\mathrm{Y}=12.2748+0.188233 \mathrm{C}^{*}$ & 0.96 \\
\hline $\mathrm{BF} / \mathrm{TBF}(\%)$ & 28.43 & 28.70 & 25.92 & 28.79 & 14.48 & - & - \\
\hline \multicolumn{8}{|c|}{ Carré } \\
\hline $\mathrm{BF}(\mathrm{g})$ & 81.08 & 130.95 & 163.73 & 283.17 & 20.74 & $\mathrm{Y}=4.97500+3.19517 \mathrm{C}^{*}$ & 0.92 \\
\hline $\mathrm{BF}(\%)$ & 8.15 & 10.32 & 12.34 & 16.34 & 20.43 & $\mathrm{Y}=5.13740+0.133024 \mathrm{C}^{*}$ & 0.97 \\
\hline $\mathrm{BF} / \mathrm{TBF}(\%)$ & 9.40 & 10.01 & 9.345 & 11.51 & 12.21 & $\mathrm{Y}=8.65528+0.0282728 \mathrm{C}^{*}$ & 0.82 \\
\hline $\mathrm{TBF}(\mathrm{g})$ & 861.98 & 1319.48 & 1819.58 & 2486.35 & 25.19 & $Y=278.550+26.8660 C^{*}$ & 0.99 \\
\hline
\end{tabular}

${ }^{\mathrm{T}}$ Muscle: muscle + intramuscular fat + intermuscular fat; BF: backfat; BF/TBF: backfat/total backfat carcass; C: level of concentrate.

${ }^{2}$ Averages followed by "*" are significant at a 5\% probability; ns - not significant. 
The bone deposition (\%) was reduced linearly, and backfat (BF) increased linearly according to the levels of concentrate; however, the relation between the backfat of the shoulder and the total backfat of the carcass $(\mathrm{BF} / \mathrm{TBF})$ was not influenced.

In the proportion of the deposition of components in the leg, it can be observed that the percentage of muscle and bone deposition in the leg decreased with the increase in the level of concentrate, and only the percentage of backfat rose linearly. Therefore, for each $1 \%$ of concentrate added to the diet, there was a reduction of $0.04 \%$ of muscle, $0.05 \%$ of bone from the leg and increase of $0.11 \%$ in BF. The percentage of deposition of the $\mathrm{BF} / \mathrm{TBF}$ ratio was not affected by the inclusion of concentrate, with an average of $22.12 \% \mathrm{BF} / \mathrm{TBF}$ of leg.

According to Rosa et al. (2005) and Furusho-Garcia et al. (2009), the bone and muscle of the rank shoulder and the leg presented early growth, but the fat presented late growth, which is in line with the behavior obtained in the present study.

The deposition of muscle and bone $(\mathrm{g})$ of the loin presented quadratic effect, with its maximum at the level of 65.79 and $51.67 \%$ of concentrate, respectively, corresponding to $529.50 \mathrm{~g}$ and $219.45 \mathrm{~g}$. Backfat presented positive linear effect, and the percentage deposition of loin muscle did not present significant effect with increase in the levels of concentrate, with an average of $55.05 \%$ of muscle in the loin. In contrast, bone deposition suffered reduction with increase in the inclusion of concentrate in the diet, promoting greater relative amount of edible portion of the cut (muscle and fat). The deposition of the loin BF grew linearly with the increase in the levels of concentrate, although the percentage of BF/TBF did not present any effect with the increase in the levels of concentrate, with an average $10.47 \%$

During body growth, the percentage of muscle in the loin remained constant $(55.05 \%)$ and at every $1 \%$ of concentrate added to the diet there was a decrease of $0.14 \%$ of bone deposition and increase of $0.21 \%$ of backfat, thus demonstrating the high rate of subcutaneous fat deposition.

The subcutaneous fat deposition of the neck, rank and carré, in absolute and relative values, presented positive linear effect according to the level of concentrate. This shows that the inclusion of concentrate in the diet elevates the deposition of subcutaneous fat, and in many cases, depending on the consumer market, this excess fat can be discarded at the moment of toillete, bringing losses to the industry.

The BF/TBF ratio in neck and rank was not affected by the increase in the levels of concentrate, with a contribution of 16.99 and $27.96 \%$ of the total backfat of the carcass, respectively. However, the $\mathrm{BF} / \mathrm{TBF}$ ratio in the carré presented increasing linear effect with the increase in the levels of concentrate added to the diet.

The deposition of total subcutaneous fat of the carcass (TBF) presented positive linear effect according to the level of concentrate added to the diet, and for every $1 \%$ of concentrate added, there was an increase of $26.87 \mathrm{~g}$ of backfat in the carcass.

Besides, when analyzing the regression equations of the percentages of $\mathrm{BF}$ deposition in the neck, rank and carré, the percentage of deposition of $\mathrm{BF}$ was more intense for the neck, followed by the rank and lastly -for the carré, with increase of $0.29 \% ; 0.19 \%$ and $0.13 \%$ $\mathrm{BF}$, respectively, for each $1 \%$ of concentrate added. Concerning the organs, the empty body weight (EBW) 
increased linearly, due to the different slaughter weights (Table 3 ).

The females fed the highest level of concentrate $(80 \%)$ were the heaviest (50.30kg live weight). All the weights of the organs presented positive linear effect with the increasing level of concentrate, except for the bladder $(\mathrm{g})$, which did not present significant effect.

Table 3. Means, coefficients of variation $(\mathrm{CV})$, regression equations and determination coefficients $\left(\mathrm{R}^{2}\right)$ of the organs in grams and percentage $(\%)$ of empty body weight $(\mathrm{EBW})$, according to the levels of concentrate in the diets

\begin{tabular}{|c|c|c|c|c|c|c|c|}
\hline \multirow{2}{*}{ Variables $^{1}$} & \multicolumn{4}{|c|}{ Level of concentrate $^{2}$} & \multirow{2}{*}{$\mathrm{CV}$} & \multirow{2}{*}{ Regression } & \multirow{2}{*}{$\mathrm{R}^{2}$} \\
\hline & 20 & 40 & 60 & 80 & & & \\
\hline $\mathrm{EBW}(\mathrm{kg})$ & 28.58 & 33.63 & 38.01 & 41.83 & 9.48 & $Y=24.7794+0.217072 C^{*}$ & 0.99 \\
\hline Tongue (g) & 86.33 & 110.67 & 109.33 & 119.33 & 12.65 & $Y=82.0000+0.488333 C^{*}$ & 0.72 \\
\hline Lung+Trach+Eso (g) & 642.67 & 687.33 & 777.67 & 778.33 & 13.01 & $Y=597.167+2.48667 C^{*}$ & 0.92 \\
\hline Heart(g) & 112.00 & 121.00 & 146.33 & 180.67 & 16.80 & $Y=82.1667+1.15667 C^{*}$ & 0.94 \\
\hline Spleen $(\mathrm{g})$ & 54.33 & 62.00 & 65.33 & 84.33 & 19.31 & $Y=43.1667+0.466667 C^{*}$ & 0.82 \\
\hline Liver (g) & 500.67 & 572.67 & 647.00 & 766.33 & 15.94 & $\mathrm{Y}=403.833+4.35667 \mathrm{C}^{*}$ & 0.99 \\
\hline Bladder (g) & 32.00 & 27.33 & 39.33 & 41.67 & 50.03 & - & - \\
\hline Kidneys (g) & 91.00 & 95.33 & 107.00 & 119.33 & 9.76 & $Y=79.0000+0.483333 C^{*}$ & 0.97 \\
\hline Reproductive S. (g) & 63.67 & 67.33 & 79.67 & 109.33 & 38.13 & $Y=42.6667+0.746667 C^{*}$ & 0.65 \\
\hline Udder (g) & 98.33 & 119.33 & 195.67 & 205.33 & 28.93 & $\mathrm{Y}=55.3333+1.98667 \mathrm{C}^{*}$ & 0.85 \\
\hline Tongue (\%) & 0.31 & 0.34 & 0.30 & 0.28 & 13.06 & - & - \\
\hline Lung+Trach+Eso $(\%)$ & 2.21 & 2.05 & 2.04 & 1.86 & 12.44 & $\mathrm{Y}=23.0163-0.00525792 \mathrm{C}^{*}$ & 0.94 \\
\hline Heart $(\%)$ & 0.39 & 0.36 & 0.39 & 0.43 & 14.24 & - & - \\
\hline Spleen $(\%)$ & 0.19 & 0.18 & 0.16 & 0.20 & 18.42 & - & - \\
\hline Liver $(\%)$ & 1.77 & 1.68 & 1.73 & 1.82 & 8.86 & - & - \\
\hline Bladder $(\%)$ & 0.12 & 0.09 & 0.09 & 0.10 & 47.18 & - & - \\
\hline Kidneys (\%) & 0.32 & 0.28 & 0.28 & 0.29 & 7.21 & $\begin{array}{c}\mathrm{Y}=0.366284- \\
0.00289729 \mathrm{C}+0.0000238867 \mathrm{C}^{2} *\end{array}$ & 0.95 \\
\hline Reproductive S. (\%) & 0.24 & 0.20 & 0.19 & 0.26 & 33.47 & - & - \\
\hline Udder $(\%)$ & 0.36 & 0.35 & 0.56 & 0.49 & 28.25 & $Y=0.289483+0.00291493 C^{*}$ & 0.56 \\
\hline TWO:LWS (\%) & 4.64 & 4.69 & 4.98 & 5.01 & 6.04 & $\mathrm{Y}=4.47824+0.00704361 \mathrm{C}^{*}$ & 0.73 \\
\hline TWO:EBW (\%) & 5.91 & 5.46 & 5.73 & 5.74 & 7.12 & - & - \\
\hline
\end{tabular}

${ }^{1}$ LWS: live weight at slaughter; EBW: empty body weight; Lung+Trach+Eso: lung + trachea + esophagus; Reproductive S.: reporoductive system; TWO: total weight of the organs, C: level of concentrate;

${ }^{2}$ Averages followed by "*" are significant at a 5\% probability; ns - not significant.

The percentage (\%EBW) of tongue, heart, spleen, liver, bladder and reproductive system was not affected by the increase in the levels of concentrate. However, the percentage of lung + trachea + esophagus reduced linearly with the increase of concentrate, and kidneys presented quadratic effect with the lowest percentage at the level of $60.71 \%$ concentrate. The udder rose linearly because of the initial stage of puberty of females; the same occurred with relation to the total weight of organs TWO/LWS. However, the TWO/EBW ratio was not influenced, with an average of $5.71 \%$.

Alves et al. (2003), working with different energy levels $(2.42 ; 2.66$; and $2.83 \mathrm{Mcal} / \mathrm{kg} \mathrm{DM})$ in the diet supplied 
to uncastrated Santa Ines lambs at 6 months of age and initial weight of 20 $\mathrm{kg} \mathrm{LW}$ and slaughtered at $33 \mathrm{~kg} \mathrm{LW}$, observed that none of the absolute weights of the organs (respiratory system, heart, liver, kidneys and spleen) were influenced by the energetic increase of the diet.

One of the explanations for such behavior can be the advanced age of the animals at the beginning of the experiment, which would probably already have all their organs developed, which would not allow effect from the diet. In contrast, in the present study, the weights of the majority of organs were significantly affected by the increase in the level of concentrate, which is probably related to the age of the animals at the beginning of the experiment, between 23 months, and its end, 6-7 months, which allowed the occurrence of influence from the diet.

According to Joy et al. (2008), breed, age, sex and slaughter weight are the main factors that influence the noncarcass components. According to Ferreira et al. (2000), the heart and respiratory system are organs that usually keep their integrity due to the priority at the utilization of nutrients, regardless of the feeding, which can be verified in the unaltered percentage participation of the heart.

However, lung + trachea + esophagus decreased linearly with increase in the level of concentrate. Besides, it was expected that, the percentage values of liver and spleen would increase as the levels of concentrate increased. According to Clementino et al. (2007), these organs have high metabolic rates, participate actively in the metabolism of nutrients and, therefore, should respond to the increase in energy intake, but this behavior was not observed.
However, Santos-Cruz et al. (2009) also claimed that both liver and spleen are organs of early growth, so this is a possible explanation for the absence of response to the increasing levels of concentrate on the percentage production of both organs in relation to EBW.

It can be observed that the gastrointestinal tract content (CGIT) reduced linearly with the increase in the dietary concentrate (Table 4), possibly because of the shorter retention time in the rumen, related to the greater passage rate. This situation allows the gastrointestinal tract to have a greater amount of energy, and thereby promotes better performance. Such fact can be proven by the higher LWS and CCW (Table 1) in the animals that received more concentrate in the diets.

Corroborating the results obtained in the present study, Carvalho et al. (2005), analyzing the non-carcass components of castrated lambs of undefined breed subjected to different pasture-based supplementation levels $(0 ; 1.0 ; 1.5 ; 2.0$; and $2.5 \%$ of LW), observed that CGIT reduced linearly with increase in the level of concentrate supplementation $(6.561 ; 6.262 ; 6.718 ; 4.680 ;$ and 4.352 $\mathrm{kg}$, respectively).

This can be explained by the difference in energy density between concentrates and forages. A food with low energy needs greater rumen storage capacity. There are other interfering factors on the tract filling, as digestibility and rate of passage, which are smaller in diets with lower content of concentrate feed. According to Carvalho et al. (2005), the decrease in the CGIT is an important commercial factor, because a lower proportion of CGIT is associated with better carcass yield and, consequently, greater proportion of edible material to the consumer. 
Table 4. Means, coefficients of variation (CV), regression equations and determination coefficients $\left(\mathrm{R}^{2}\right)$ of the weight of the gastrointestinal tract content (CGIT) and of viscera in grams and percentage (\%) of empty body weight (EBW), according to the increasing levels of concentrate in the diets

\begin{tabular}{|c|c|c|c|c|c|c|c|}
\hline \multirow{2}{*}{ Variables $^{1}$} & \multicolumn{4}{|c|}{ Level of concentrate $^{2}$} & \multirow{2}{*}{$\mathrm{CV}$} & \multirow{2}{*}{ Regression } & \multirow{2}{*}{$\mathrm{R}^{2}$} \\
\hline & 20 & 40 & 60 & 80 & & & \\
\hline CGIT (kg) & 7.18 & 6.26 & 5.99 & 5.90 & 13.34 & $Y=7.34516-0.0201189 C^{*}$ & 0.82 \\
\hline Rumen (g) & 669.00 & 610.33 & 560.33 & 573.67 & 9.94 & $\mathrm{Y}=55.3333+1.98667 \mathrm{C}^{*}$ & 0.81 \\
\hline Reticulum (g) & 109.67 & 120.00 & 104.00 & 108.33 & 15.31 & - & - \\
\hline Omasum (g) & 75.00 & 77.67 & 82.33 & 75.67 & 23.62 & - & - \\
\hline Abomasum (g) & 164.00 & 168.33 & 168.00 & 173.33 & 23.41 & - & - \\
\hline SI (g) & 540.80 & 520.00 & 560.00 & 512.33 & 18.90 & - & - \\
\hline $\mathrm{LI}(\mathrm{g})$ & 403.00 & 345.33 & 410.67 & 443.33 & 12.91 & $Y=354.000+0.931667 C^{*}$ & 0.70 \\
\hline Rumen (\%) & 2.30 & 1.81 & 1.49 & 1.38 & 10.29 & $Y=2.50109-0.0150973 C^{*}$ & 0.93 \\
\hline Reticulum (\%) & 0.39 & 0.36 & 0.28 & 0.26 & 19.08 & $Y=0.446002-0.00243680 C^{*}$ & 0.94 \\
\hline Omasum (\%) & 0.26 & 0.23 & 0.21 & 0.18 & 18.83 & $Y=0.286286-0.00130257 C^{*}$ & 0.98 \\
\hline Abomasum (\%) & 0.54 & 0.50 & 0.46 & 0.42 & 25.44 & $Y=0.582579-0.00205796 C^{*}$ & 0.99 \\
\hline SI $(\%)$ & 1.90 & 1.61 & 1.47 & 1.22 & 16.69 & $\mathrm{Y}=2.08338-0.0107347 \mathrm{C}^{*}$ & 0.98 \\
\hline LI $(\%)$ & 1.33 & 1.03 & 1.14 & 1.07 & 15.06 & - & - \\
\hline
\end{tabular}

${ }^{\mathrm{T}}$ CGIT: gastrointestinal tract content; SI: small intestine; LI: large intestine; C: level of concentrate.

${ }^{2}$ Averages followed by "*" are significant at a 5\% probability; ns - not significant.

The percentage values of rumen, reticulum, omasum, abomasum and small intestine in relation to EBW presented decreasing linear effect with the increasing levels of concentrate in the diets. Therefore, analyzing the weight of the viscera, we can see that only the weight of the rumen presented negative linear effect, and the weight of reticulum, omasum, abomasum and small intestine were not affected by the increase in the levels of concentrate in the diet. This result is associated with the dilution effect, with higher carcass weights, has been a decrease in the relative gastrointestinal tract size.

McLeod \& Baldwin (2000), evaluating the effect of two roughage:concentrate ratios (75R:25C and 25R:75C) on the growth of visceral organs of crossbred lambs (three months), observed that the weight of the digestive tract (whole gastrointestinal system) and its percentage relation with EBW increased in the animals fed $75 \%$ roughage.

According Joy et al. (2008), the quantity of digesta that reaches the small intestine of the animals on diets with a high level of concentrate is not enough to promote greater tissue development, whereas diets with more roughage with a great amount of digesta promote more growth of the viscera. Likewise, in the present study, the increase in the levels of concentrate might have fostered a lower volume of digesta, bringing about smaller development of the viscera with percentage reduction (in relation to EBW) according to the increase in the levels of concentrate. Neither weight of the blood nor its percentage in relation to EBW was affected by the increasing levels of concentrate in the diet (Table 5).

The absolute weights of skin + wool, head and paws presented positive linear effect according to the level of concentrate in the diet; however the weight of skin + wool, in percentage to EBW, was not influenced by the increase in the levels of concentrate in the diets. The relative weight of head and paws (\%), in turn, presented decreasing linear effect, with reduction according to the increase in the animal 
body weight, which is related to early development.

The absolute and relative weights (\%EBW) of the adipose deposits were influenced positively and linearly according to the increasing levels of concentrate, except for the relative weight $(\% \mathrm{EBW})$ of the omental + mesenteric fat. Such observation demonstrates that in the intermediate metabolism, the greater energy availability in the organism comes from the omental and mesenteric fat, whereas the subcutaneous fat can be converted into reserve fat, less readily available.

Table 5. Means, coefficients of variation (CV), regression equations and determination coefficients $\left(\mathrm{R}^{2}\right)$ of byproducts and fat deposits in grams and percentage $(\%)$ of empty body weight (EBW) according to the levels of concentrate in the diets

\begin{tabular}{|c|c|c|c|c|c|c|c|}
\hline \multirow{2}{*}{ Variables $^{1}$} & \multicolumn{4}{|c|}{ Level of concentrate $^{2}$} & \multirow{2}{*}{$\mathrm{CV}$} & \multirow{2}{*}{ Regression } & \multirow{2}{*}{$\mathrm{R}^{2}$} \\
\hline & 20 & 40 & 60 & 80 & & & \\
\hline Blood $(\mathrm{kg})$ & 1.26 & 2.12 & 1.56 & 1.78 & 42.69 & - & - \\
\hline Skin + Wool (kg) & 4.65 & 5.19 & 5.46 & 6.12 & 15.92 & $\mathrm{Y}=4.17958+0.023522 \mathrm{C}^{*}$ & 0.93 \\
\hline Head $(\mathrm{kg})$ & 1.21 & 1.29 & 1.33 & 1.39 & 7.73 & $\begin{array}{l}\mathrm{Y}=1.15917+ \\
0.00290500 \mathrm{C}^{*}\end{array}$ & 0.96 \\
\hline Paws (g) & 683.67 & 717.67 & 746.33 & 806.67 & 7.90 & $Y=639.167+1.98833 C^{*}$ & 0.99 \\
\hline Blood (\%) & 4.35 & 6.46 & 4.14 & 4.24 & 48.62 & - & - \\
\hline Skin + Wool $(\%)$ & 16.32 & 15.37 & 14.36 & 14.59 & 10.51 & - & - \\
\hline Head $(\%)$ & 4.19 & 3.85 & 3.53 & 3.33 & 5.99 & $Y=4.43914-0.0142999 C^{*}$ & 0.99 \\
\hline Paws $(\%)$ & 2.30 & 2.14 & 1.98 & 1.93 & 4.79 & $\begin{array}{l}\mathrm{Y}=2.39987- \\
0.00620692 \mathrm{C}^{*}\end{array}$ & 0.96 \\
\hline \multicolumn{8}{|c|}{ Fat deposits } \\
\hline Ome + Mes $(\mathrm{kg})$ & 1.05 & 1.54 & 2.04 & 2.21 & 23.25 & $\begin{array}{c}\mathrm{Y}=0.720500+ \\
0.0198033 \mathrm{C}^{*}\end{array}$ & 0.92 \\
\hline Kidney (g) & 399.33 & 433.33 & 822.00 & 981.00 & 44.45 & $Y=125.500+10.6683 C^{*}$ & 0.90 \\
\hline Subcutaneous $(\mathrm{g})$ & 861.98 & 1319.48 & 1819.58 & 2486.35 & 23.45 & $Y=278.550+26.8660 C^{*}$ & 0.99 \\
\hline Ome + Mes $(\%)$ & 4.01 & 4.63 & 5.70 & 5.28 & 24.93 & - & - \\
\hline Kidney (\%) & 1.52 & 1.31 & 2.16 & 2.33 & 44.11 & $\begin{array}{c}Y=0.983052+ \\
0.0166120 C^{*}\end{array}$ & 0.74 \\
\hline Subcutaneous $(\%)$ & 3.10 & 3.89 & 4.99 & 5.91 & 18.67 & $Y=2.08374+0.0477156 C^{*}$ & 0.99 \\
\hline
\end{tabular}

The non-carcass components in absolute values $(\mathrm{kg})$ demonstrated positive linear effect, as well as the percentage of fat deposits, according to the increase of concentrate in the diet (Table 6).

However, the percentage of viscera and byproducts presented negative linear effect with the increase in the levels of concentrate in the diet, which explains the increase in carcass yield. Only the percentage of total weight of the organs was not affected by the levels of concentrate. Byproducts represent a greater percentage of the non-carcass components.

The non-carcass components, when related to live weight, presented positive linear effect; however, when they were related to live weight at slaughter, there was no effect for the increasing levels of concentrate, with an average of $40.42 \%$. It is probably that variation is due the filling of the tract gastro intestinal. 
Rev. Bras. Saúde Prod. Anim., Salvador, v.15, n.4, p.1038-1051 out./dez., 2014 http://www.rbspa.ufba.br ISSN 15199940

Table 6. Means, coefficients of variation (CV), regression equations and determination coefficients $\left(\mathrm{R}^{2}\right)$ of non-carcass components (NCC), percentage of the components in relation to the NCC and the relation with live weight and live weight at slaughter, according to the levels of concentrate in the diets

\begin{tabular}{|c|c|c|c|c|c|c|c|}
\hline \multirow{2}{*}{ Variables $^{1}$} & \multicolumn{4}{|c|}{ Level of concentrate $^{2}$} & \multirow{2}{*}{$\mathrm{CV}$} & \multirow{2}{*}{ Regression } & \multirow{2}{*}{$\mathrm{R}^{2}$} \\
\hline & 20 & 40 & 60 & 80 & & & \\
\hline NCC (kg) & 13.67 & 16.33 & 17.75 & 20.06 & 10.01 & $Y=11.8035+0.102972 C^{*}$ & 0.99 \\
\hline TWO (\%) & 12.29 & 11.49 & 12.25 & 11.99 & 8.77 & - & - \\
\hline Viscera $(\%)$ & 13.71 & 11.51 & 10.07 & 9.49 & 14.29 & $\mathrm{Y}=14.7169-0.0704104 \mathrm{C}^{*}$ & 0.94 \\
\hline Byproducts (\%) & 57.03 & 56.78 & 51.36 & 50.35 & 7.03 & $Y=60.2445-0.127288 C^{*}$ & 0.87 \\
\hline Fat deposits $(\%)$ & 16.97 & 20.22 & 26.31 & 28.17 & 14.93 & $Y=13.0004+0.198353 C^{*}$ & 0.96 \\
\hline NCC:LW (\%) & 34.76 & 38.72 & 38.56 & 39.81 & 7.29 & $\mathrm{Y}=34.2180+0.0748642 \mathrm{C}^{*}$ & 0.77 \\
\hline NCC:LWS (\%) & 37.85 & 41.26 & 40.72 & 41.85 & 7.51 & - & - \\
\hline
\end{tabular}

${ }^{1} \mathrm{NCC}=$ non-carcass components; TWO = total weight of the organs; LW = live weight; LWS: live weight at slaughter; $\mathrm{C}=$ level of concentrate.

${ }^{2}$ Averages followed by "*" are significant at a $5 \%$ probability; ns = not significant.

The weights of the cuts are positively influenced by the increase in the live body weight promoved by the high levels of concentrate. The increase in the levels of concentrate $\mathrm{e}$ and consequently higher energy density of the diet may promote a lower percentage of viscera and greater yield of the edible parts of the carcass. Is important to mention that due to the higher weight gain occurs a dilution effect, which also impacts on the proportional reduction in the gastrointestinal tract

The elevation in the levels of concentrate promotes increase in the deposition of subcutaneous fat of the commercial meat cuts. Non-carcass components represent an elevated percentage of LW and LWS, which explains the industrial utilization of these components.

\section{REFERENCES}

ALVES, K.S.; CARVALHO, F.F.R.; FERREIRA, M.A.; VÉRAS, A.S.C.; MEDEIROS, A.N.; NASCIMENTO, L.R.S.; ANJOS, A.V.A. Níveis de energia em dietas para ovinos Santa Inês: características de carcaça e constituintes corporais. Revista Brasileira de Zootecnia, v.32, n.6, p.1927-1936, 2003. Supl. 2.

CARVALHO, S.; BROCHIER, M.A.; PIVATO, J.; TEIXEIRA, R.C.; KIELING, R. Ganho de peso, características da carcaça e componentes não-carcaça de cordeiros da raça Texel terminados em diferentes sistemas alimentares. Ciência Rural, v.37, n.3, p.821-827, 2007.

CARVALHO, S.; VERGUEIRO, A.; KIELING, R.; TEIXEIRA, R.C.; PIVATO, J.; VIERO, R.; CRUZ, A.N. Avaliação da suplementação concentrada em pastagem de Tifton-85 sobre os componentes não carcaça de cordeiros. Ciência Rural, v.35, n.2, p.435-439, 2005.

CLEMENTINO, R.H.; SOUSA, W.H.; MEDEIROS, A.N.; CUNHA, M.G.G.; GONZAGA NETO, S.; CARVALHO, F.F.R.; CAVALCANTE, M.A.B. Influência dos níveis de concentrado sobre os cortes comerciais, os constituintes não-carcaça e os componentes da perna de cordeiros 
Rev. Bras. Saúde Prod. Anim., Salvador, v.15, n.4, p.1038-1051 out./dez., 2014 http://www.rbspa.ufba.br ISSN 15199940

confinados. Revista Brasileira de

Zootecnia, v.36, n.3, p.681-688, 2007.

FERREIRA, M.A.; VALADARES

FILHO, S.C.; MUNIZ, E.B.H.

Características das carcaças, biometria do trato gastrintestinal, tamanho dos órgãos internos conteúdo gastrintestinal de bovinos os F1 Simental x Nelore alimentados com vários níveis de concentrados. Revista Brasileira de Zootecnia, v.29, n.4, p.1174-1182, 2000.

FRESCURA, R.B.M.; PIRES, C.C.; SILVA, J.H.S.; MULLER, L.; CARDOSO, A.; KIPPERT, C.J.; PERES NETO, D.; SILVEIRA, C.D.; ALEBRANTE, L.; THOMAS, L. Avaliação das proporções dos cortes da carcaça, características da carne e avaliação dos componentes do peso vivo de cordeiros. Revista Brasileira de Zootecnia, v.34, p.167-174, 2005.

FURUSHO-GARCIA, I.F.; PEREZ, J.R.O.; PEREIRA, I.G.; COSTA, T.I.R.; MARTINS, M.O. Estudo alométrico dos tecidos da carcaça de cordeiros Santa Inês puros ou mestiços com Texel, Ile de France e Bergamácia. Revista Brasileira de Zootecnia, v.38, n.3, p.539-546, 2009.

GALVANI, D.B.; PIRES, C.C.; OLIVEIRA, F.; WOMMER, T.P.; JOCHIMS. Crescimento alométrico dos componentes da carcaça de cordeiros Texel $\times$ Ile de France confinados do desmame aos $35 \mathrm{~kg}$ de peso vivo. Ciência Rural, v.38, n.9, p.2574-2578, 2008.

JOY, M.; RIPOLL, G.; DELFA, R. Effects of feeding system on carcass and non-carcass composition of Churra Tensina light lambs. Small Ruminant Research, v.78, p.123-133, 2008.

LAWRENCE, T. L. J.; FOWLER, V. R. Growth of Farm Animals. 2.ed.
Wallingford, Oxon: Cabiternational, 2002.347p.

McLEOD, K.R.; BALDWIN, R.L. Effects of diet forage:concentrate ratio and metabolizable energy intake on visceral organ growth and in vitro oxidative capacity of gut tissues in sheep. Journal Animal Science, v.78, p. 760770, 2000 .

MEDEIROS, G.R.; CARVALHO, F.F.R.; BATISTA, A.M.V.; DUTRA JUNIOR, W.D.; SANTOS, G.R.A.; ANDRADE, D.K.B. Efeito dos níveis de concentrado sobre as características de carcaça de ovinos Morada Nova em confinamento. Revista Brasileira de Zootecnia, v.38, n.4, p.718-727, 2009.

NATIONAL RESEARCH COUNCIL NRC. Nutrient requirements of small ruminants. Washington, D.C.: National Academy of Science, 2007. 362p.

PINHEIRO, R.S.B.; JORGE, A.M.; MOURÃO, R.C.; POLIZEL NETO, A.; ANDRADE, E.N.; GOMES, H.F.B. Qualidade da carne de cordeiros confinados recebendo diferentes relações de volumoso:concentrado na dieta.

Ciência e Tecnologia de Alimentos, v.29, n.2, p.407-411, 2009.

ROSA, G.T.; PIRES, C.C.; SILVA, J.H.S.; MOTTA, O.S. Crescimento alométrico de osso, músculo e gordura em cortes da carcaça de cordeiros Texel segundo os métodos de alimentação e peso de abate. Ciência Rural, v35, n.4, p.870-876, 2005.

SANTOS, C.L.; PEREZ, J.R.O.; MUNIZ, J.A.; GERASEEV, L.C.; SIQUEIRA, E.R. Desenvolvimento relativo dos tecidos ósseo, muscular e adiposo dos cortes da carcaça de cordeiros Santa Inês. Revista Brasileira de Zootecnia, v.30, n.2, p.487-492, 2001. 
SANTOS-CRUZ, C.; PEREZ, J.R.O.; MUNIZ, J.A.; CRUZ, C.A.C.;

ALMEIDA, T.R.V. Desenvolvimento dos componentes do peso vivo de cordeiros Santa Inês e Bergamácia abatidos em diferentes pesos. Revista Brasileira de Zootecnia, v.38, n.5, p.923-932, 2009.

SILVA SOBRINHO, A.G.; MACHADO, M.R.F.; GASTALDI, K.A.; GARCIA, C.A. Efeitos da relação volumoso:concentrado e do peso ao abate sobre os componentes da perna de cordeiros Ile de France x Ideal confinados. Revista Brasileira de Zootecnia, v.31, n.2, p.1017-1023, 2002. Supl.
UNIVERSIDADE FEDERAL DE VIÇOSA - UFV. Manual de utilização do Programa SAEG (Sistema para Análises Estatísticas e Genéticas). Viçosa, MG: Universidade Federal de Viçosa, 1997. 59p.

YAMAMOTO, S.M.; MACEDO, F.A.F.; MEXIA, A.A.; ZUNDT, M.; SAKAGUTI, E.S.; ROCHA, G.B.L.; REGAÇONO, K.C.T.; MACEDO, R.M.G. Rendimentosdos cortes e não componentes das carcaças de cordeiros terminados com dietas contendo diferentes fontes de óleo vegetal. Ciência Rural, v.34, n.6, p.1909-1913, 2004.

Data de recebimento: 21/01/2014

Data de aprovação: 01/12/2014 